\title{
Synthetic Curcumin Derivatives Inhibit Jun-Fos-DNA Complex Formation
}

\author{
Hyun-Kyung Kim and Chul-Hak Yang \\ School of Chemistry, College of Natural Sciences, Seoul National Lniversity, Seoul 151-747, Korea \\ Received Mav 17,2004
}

\begin{abstract}
Jun/Fos. a crucial factor in transmitting the tumor-promoting signal from the extracellular environment to the nuclear transcription machinery. has a dimerization interface possessing several coiled stnuctural properties. Jun and Fos can interact with the DNA regulatory region. AP-1 (Activator Protein-1), which is composed of 5'-TGAC/GTCA-3'. ' Curcumin is a well-known anticancer and anti-inflammatory compound. ${ }^{2.5}$ It also acts as an inhibitor of the Jun-Fos function. c-Fos and c-Jun with a bZIP region are overexpressed in BL2I E. coll and purified with an $\mathrm{Ni}^{2-}$ affinity column. The inlubitors of Fos-Jun-AP-l complex formation were searched through the EMSA (electrophoresis mobility shift assay) experiment. and new curcuminoids were synthesized and investigated as to their inhibitory effect on the same system. Two curcuminoids showed a stronger inhibitory effect than curcumin. This inhibitory activity was quantified with EMSA. 1.7-bis(4-methyl)-1.6heptadiene-3.5-dione (BJCO03) and 1.7-bis(4-hydroxy-5-methoxy-3-nitrophenyl)-1.6-heptadiene-3.5-dione (BJC005) showed remarkably high inhibitory activities. IC $_{S(1)}$ of 1.7-bis(4-methyl)-1.6-heptadiene-3.5-dione (BJC003) and 1.7-bis(4-hydroxy-5-methoxy-3-nitrophenyl)-1.6-heptadiene-3.5-dione (BJC005) are $8.98 \mu \mathrm{M}$ and $5.40 \mu \mathrm{M}$. respectively. However. 1.7-bis(4-methỵl-3-nitrophenyl)-1.6-heptadiene-3.5-dione (BJC004) did not show inhibitory activity
\end{abstract}

Key Words : Curcumin. Jun-Fos-AP-1 complex, 1.7-Bis(4-methyl)-1.6-heptadiene-3.5-dione (BJC003). 1,7-Bis(4-methyl-3-nitrophenyl)-1.6-heptadiene-3,5-dione (BJCO04), 1.7-Bis(4-hydroxy-5-methosy-3-nitrophenyl)-1.6-heptadiene-3.5-dione (BJC005)

\section{Introduction}

A variety of processes have evolved in eukaryotic cells for coupling envirommental cues to the selective regulation of gene expression. Cell surface stimuli evoke a series of intracellular signals that ultimately affect the levels or activities of proteins that bind to transcriptional control elements. Many of these transcription factors interact with DNA in the form of dimeric complexes that employ a limited set of defined structural motifs. ${ }^{4}$ These conserved domains mediate interactions that generate an array of heterodimeric protein complexes formed from the products of related gene family members. In many cases, protein dimers may have distinct transcriptional properties although they exhibit similar DNA-binding specificities. The class of transcription factors that contain the lencine zipper motif exemplifies this phenomenon. They include SV40. the human metallothionein $\| A$ gene. and the control regions of genes whose expression is stimulated by treatment of cells with the phorbol ester. a tumor promoting agent. A number of AP-1-related reports suggest that over-expression. irregulation. and transformation could induce tumor progression and cancer-cell growth. ${ }^{\circ}$ AP-1 has two oncogene products with its own components, namely, Jun and Fos. In this report. in order to search for a more potent Fos/Jun inhibitor. we synthesized a series of symmetrical curcumin analogs by Pabons method ${ }^{2}$ and tested their inhibitory activity by performing gel-retardation assay.

\footnotetext{
${ }^{*}$ Corresponding Author. e-mail: chulyangidaplaza.snu.ac.kr
}

\section{Experimental Sections}

Reagents. Chemicals for synthesis and all other reagents and solvents were purchased from Sigma-Aldrich Chemical Co. or TCI (Tokyo. Japan). The wb-fos. wb-jun, pTK-fos and pTK-jun genes were kindly provided by Dr. T. Curran, St. Jude Children Hospital.

Synthesis of curcumin derivatives. For synthesis of 1.7bis(4-methyl)-1,6-heptadiene-3.5-dione (BIC003). according to the reported method, ${ }^{2}$ - - methly-benzaldehyde $(2.68 \mathrm{~g}$. 0.02 mole) and tributyl borate (1.1l g. 0.055 mole) were dissolved in $10 \mathrm{~mL}$ of dry ethyl acetate and were heated to $100{ }^{\circ} \mathrm{C}$. Subsequently the reaction product from $1.099 \mathrm{~mL}$ of 2.4-pentadione and $0.5 \mathrm{~g}$ boric anlydride $(0.07 \mathrm{~mole})$ was added and the mixture heated for $30 \mathrm{~mm}$, while stirring, in order to achieve a homogeneous mixture. After cooling to 85 ${ }^{\circ} \mathrm{C}, 0.05 \mathrm{~mL}$ of buty lamine was added every $5 \mathrm{~min}$ (total 0.2 $\mathrm{mL}$ ). Finally. after having been maintained for $30 \mathrm{~min}$ at 100 ${ }^{\circ} \mathrm{C}$, while stirring, the mixture turned brown. After cooling to $50^{\circ} \mathrm{C} .15 \mathrm{~mL}$ of $0.4 \mathrm{~N}$ hydrochloric acid $\left(60^{\circ} \mathrm{C}\right)$ was added. the mixture was then stirred for another $30 \mathrm{~min}$. after which $20 \mathrm{~mL}$ of ethyl acetate was added. The layers were separated, and the aqueous layer was extracted once with 5 $\mathrm{mL}$ of ethyl acetate. The combined ethyl acetate layers were washed acid-free. dried over magnesium sulfate and evaporated. The residue was dissolved in chloroform/methanol ( $2: 1)$ and subsequently cooled. after which the crystals were sucked off. With the same method, 1.7-bis(4-methyl-3nitrophenyl)-1.6-heptadiene-3.5-dione (BJC004) was also obtained by the same synthetic method. The residue was 
dissolved in methylene chloride/methanol $(2: 1)$ and subsequently cooled. after which the crystals were sucked off.

Also applying the same method. 1.7-bis(4-hydroxy-5methoxy-3-nitrophenyl)-1.6-heptadiene-3.5-dione (BJC005) was obtained. The residue was dissolved in DMSO/ methylene chloride (1 : 1.5) and subsequently cooled. After that the solution was extracted once with $5 \mathrm{~mL}$ of ethyl acetate and evaporated.

Instrumental analysis. ${ }^{3} \mathrm{H}$ NMR spectra were recorded with TMS as an internal standard at $300 \mathrm{MHz}$ on a BRUKER AVANCE DPX-300 NMR spectrometer. HREIMS data were taken with a JEOL JMS AX505WA mass spectrometer operating at $70 \mathrm{eV}$. The melting point was

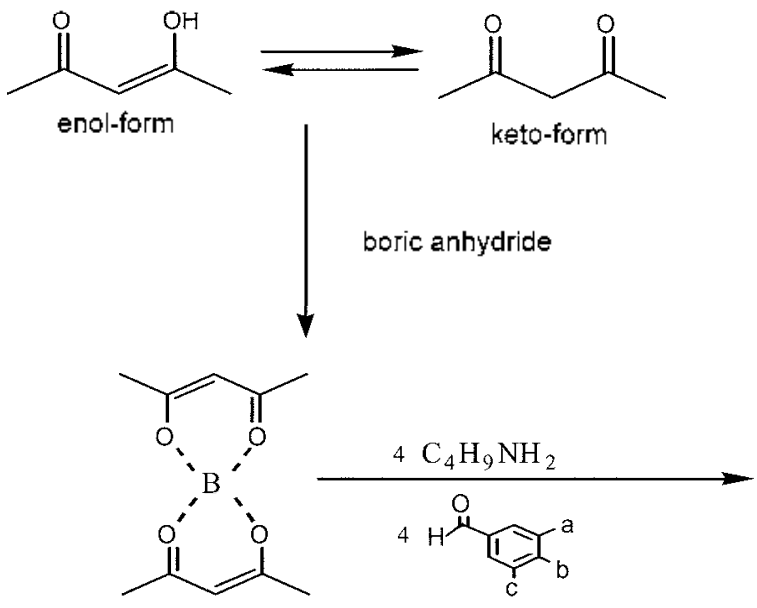

fixed enol-form ; boron complex

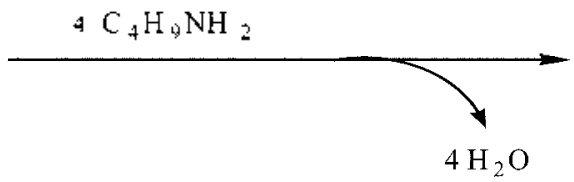<smiles></smiles><smiles>Cc1cc(/C=C/C2=COOC(/C=C/c3cc(C)c(Br)c(Br)c3)=C2)cc(Br)c1Br</smiles><smiles>Cc1cc(/C=C/C2=C[B]OC(/C=C/c3cc(C)c(Br)c(Br)c3)=C2)cc(Br)c1P</smiles><smiles>Cc1cc(/C=C/C(=O)/C=C(O)/C=C/c2cc(C)c(Br)c(Br)c2)cc(Br)c1Br</smiles>

\begin{tabular}{|c|c|c|c|}
\hline & BJC003 & BJC004 & BJC005 \\
\hline a & $-\mathrm{H}$ & $-\mathrm{NO}_{2}$ & $-\mathrm{NO}_{2}$ \\
\hline $\mathrm{b}$ & $-\mathrm{CH}_{3}$ & $-\mathrm{CH}_{3}$ & $-\mathrm{OH}$ \\
\hline $\mathrm{c}$ & $-\mathrm{H}$ & $-\mathrm{H}$ & $-\mathrm{OCH}_{3}$ \\
\hline
\end{tabular}

Scheme 1. Synthesis of curcumin derivatives 
were purified by nickel-chelated affinity chromatography (Hisøbind ${ }^{\mathbb{S}}$ Resin. Novagen) in the presence of guanidine and refolded by extensive dialysis against a dialysis buffer (50 $\mathrm{mM} \mathrm{NaCl} .25 \mathrm{mM}$ Tris-HCl. $1 \mathrm{mM}$ EDTA. $1 \mathrm{mM}$ DTT $\mathrm{pH}$ 7.4).

Labeling and purification of AP-1 DNA. Radiolabeled DNA probe was prepared by 3.5 pmole of AP- 1 consensus oligonucleotide (Promega) with $10 / \mathrm{Ci}\left[\gamma^{3 i}\right.$ P]ATP (Amersham pharmacia) and $\mathrm{T} 4$ polynucleotide kinase (TAKARA) and efficiently removed precursor from DNA labeled by Quick Spin G-25 Sephadex columns (Boehringer Mannheim).

EMSA (Gel retardation assay). A DNA binding reaction was carried out by mixing $5 \mu \mathrm{L}$ Fos-Jun heterodimeric complex and $0.2 \mu \mathrm{Ci}$ probe DNA in a gel shift buffer $(20 \%$ glycerol. $5 \mathrm{mM}$ EDTA. $2.5 \mathrm{mM}$ DTT. $25 \mathrm{mM} \mathrm{NaCl} .50 \mathrm{mM}$ Tris- $\mathrm{HCl}(\mathrm{pH} 7.5) .0 .01 \mathrm{mg} / \mathrm{mL}$ poly (dI-dC)). After one hour incubation at room temperature. $10 \times$ loading buffer (DNA binding buffer with bromophenol blue dye) was added. Samples were resolved on a $6 \%$ nondenatured gel $(5 \times$ TBE $0.70 \mathrm{~mL} .20 \%$ acryl-bis $(80: 1) 2.1 \mathrm{~mL} .95 \%$ gly cerol 0.21 $\mathrm{mL}$. dd $\mathrm{H}_{3} \mathrm{O} 3.75 \mathrm{~mL} .1 .5 \%$ APS $0.35 \mathrm{~mL}$. TEMED $15 \mu \mathrm{L}$ ) in $0.5 \times$ TBE buffer. The gel was prepared at 100 volts for $1-$ 1.5 hrs. then with a circulating buffer and run at 120 volts until no more bromophenol blue dye was passed out. The retarded gel was wrapped with a vinyl envelope placed against a piece of $\mathrm{X}$-ray film. and underwent an autoradiogram exposure overnight at $-70^{\circ} \mathrm{C}$. The exposed film was then developed and fixed.

\section{Results and Discussion}

Synthesis of curcumin derivatives. The preparation of curcumin derivatives BJC003. BJCO04 and BJCO05 is shown in Scheme 1 and has been reported in detail elsewhere. ${ }^{2}$

1,7-Bis(4-methyl)-1,6-heptadiene-3,5-dione (BJC003) The yield is $2.11 \mathrm{~g}(70 \%)$ consisting of bright yellow powder. mp $209-210^{\circ} \mathrm{C}:{ }^{l} \mathrm{H}$ NMR: $\left(\mathrm{CDCl}_{3}\right) \delta 2.38(s .6 \mathrm{H}$. $\left.2 \times \mathrm{CH}_{3} \mathrm{C}_{6} \mathrm{H}_{4}-\right) .5 .84\left(\mathrm{~s} .1 \mathrm{H} .=\mathrm{CH}_{\mathrm{a}}-\right) .6 .60(d . J=13 \mathrm{~Hz}, 2 \mathrm{H}$. $\left.2 \times-\mathrm{CH}_{\mathrm{b}}=\mathrm{CH}_{-}-\right) .7 .35\left(m, 6 \mathrm{H}, 2 \times-\mathrm{C}_{6} \mathrm{H}_{4}-\right) .7 .66(d, J=13 \mathrm{~Hz}$. $2 \mathrm{H} .2 \times-\mathrm{CH}_{\mathrm{c}}=\mathrm{CH}_{\mathrm{b}}-$ ). HREIMS $\mathrm{m} / \mathrm{z}$ calcd for $\mathrm{C}_{21} \mathrm{H}_{2 \mathrm{c}} \mathrm{O}_{2}$ 304.1463 obsd 304.1469 (Fig. 1).

1,7-Bis(4-methyl-3-nitrophenyl)-1,6-heptadiene-3,5-dione (BJC004) The yield is $2.16 \mathrm{~g}(55 \%)$ consisting of yellow powder mp $234-235^{\circ} \mathrm{C}$ : ${ }^{l} \mathrm{H}$ NMR: $\left(\mathrm{CDCl}_{\mathbf{j}}\right) \delta 2.66$ (s. $6 \mathrm{H}, 2 \times \mathrm{CH}_{3} \mathrm{C}_{6} \mathrm{H}_{4}$-) 5.90 (s. $1 \mathrm{H} .=\mathrm{CH}_{\mathrm{a}}$-) $6.70(d, J=13$ $\left.\mathrm{Hz}, 2 \mathrm{H}, 2 \times-\mathrm{CH}_{\mathrm{b}}=\mathrm{CH}_{\mathrm{c}}-\right) .7 .58\left(m, 6 \mathrm{H}, 2 \times-\mathrm{C}_{6} \mathrm{H}_{j}-\right) .8 .19(d . J$ $=13 \mathrm{~Hz}, 2 \mathrm{H}, 2 \times-\mathrm{CH}_{\mathrm{c}}=\mathrm{CH}_{\mathrm{b}}-$ ). HREIMS $\mathrm{m} / \mathrm{z}$ calcd for $\mathrm{C}_{31} \mathrm{H}_{1} \mathrm{O}_{6} \mathrm{~N}_{2} 394.1165$, obsd 398.1157 (Fig. 2).

1,7-Bis(4-hydroxy-5-methoxy-3-nitrophenyl)-1,6-heptadiene-3,5-dione (BJC005) The yield is $0.5 \mathrm{~g}(10 \%)$ consisting of brownish red powder. mp decomposed at 220 ${ }^{\circ} \mathrm{C}:{ }^{1} \mathrm{H}$ NMR: (DMSO-d $) \delta 6.13\left(s, 1 \mathrm{H},=\mathrm{CH}_{\mathrm{a}}-\right), 6.98(d$. $\left.2 \mathrm{H} .2 \times-\mathrm{CH}_{b}=\mathrm{CH}_{\mathrm{c}}-\right), 7.8\left(\right.$ s. $\left.2 \mathrm{H}, 2 \times-\mathrm{C}_{6} \mathrm{H}_{\mathrm{i}}-\right), 7.6($ s. $2 \mathrm{H} .2 \mathrm{x}-$

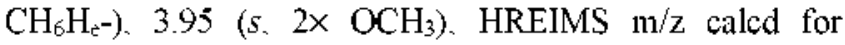
$\mathrm{C}_{21} \mathrm{H}_{18} \mathrm{O}_{10} \mathrm{~N}_{2} 458.0961$. obsd458.0982 (Fig. 3).

Establishment of Jun-Fos assay system (Fos-Jun-AP-1 complex). We established on assay system to screen the inhibitors against Fos-Jun-DNA complex formation. This sy'stem comprises a gel retardation assay. which contains the Fos/Jun dimer, radio-labeled AP-1 DNA and inhibitor. If curcumin derivatives inhibit the formation of complex. a decrease in the band of retardation can be observed on X-ray film.

Jun and Fos proteins induced by IPTG were overexpressed in E.coli BL21 ${ }^{9.10}$ and Jun and Fos proteins were clearly shown at nearly $14 \mathrm{kDa}$ and $15 \mathrm{kDa}$. Both proteins were efficiently expressed in $E$. coll and were found in the soluble fraction of the crude cell lysate ${ }^{10}$ However. Fos was easily cracked by sonication and enzymatic lysis. We could obtain intact Fos in $8 \mathrm{M}$-guanidine solution. The proteins were purified from the clarified cell lysate in a single step as described under "His-Bind Kits" from Novagene. 11.12 They'

(a)

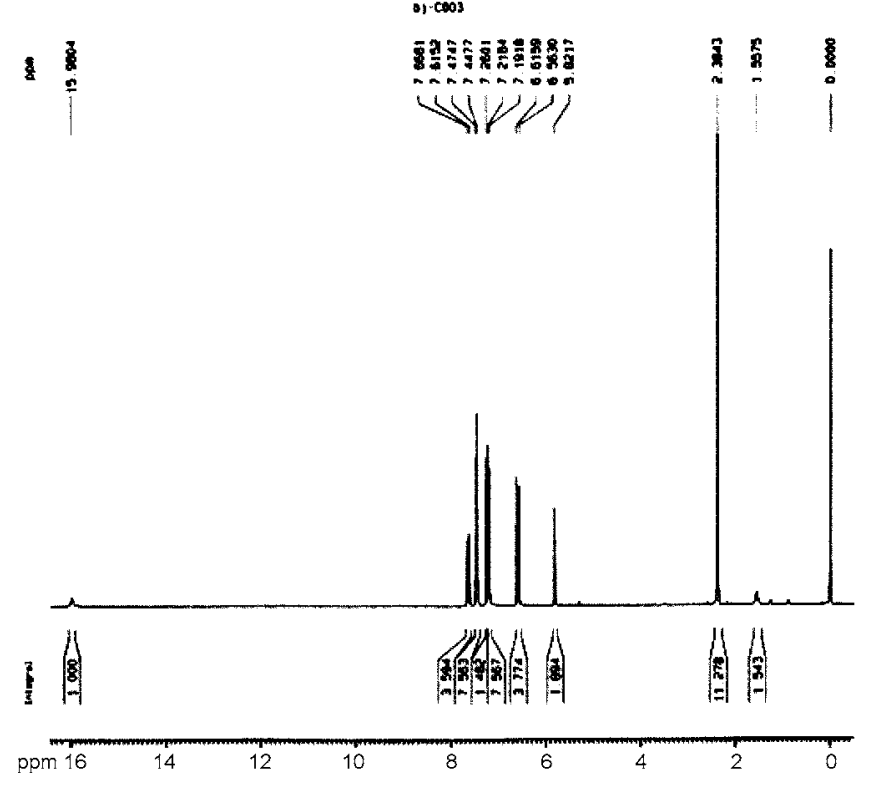

(b)

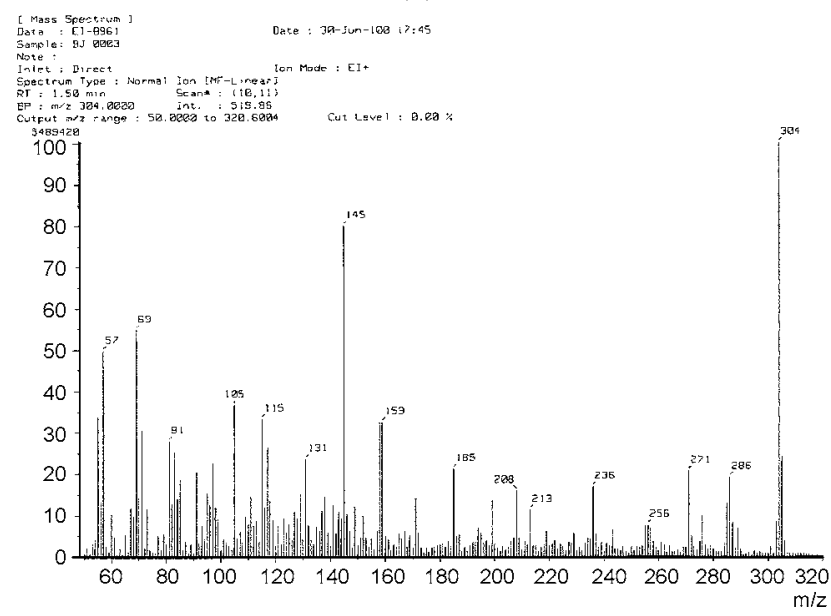

Figure 1. 'H NMR spectrum of 1,7-bis(4-methyl)-1,6-heptadiene3,5-dione (B.TCOO3) (a). Mass spectrum of 1,7-bis(4-methyl)-1,6heptadiene-3,5-dione (BJC003) (b). 
(a)

0.4

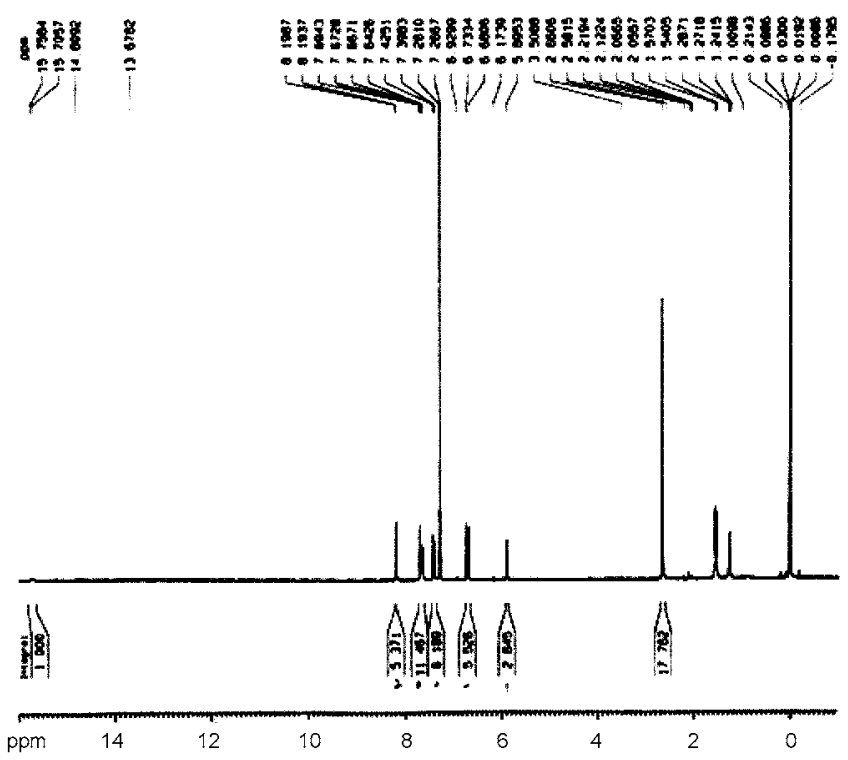

(b)

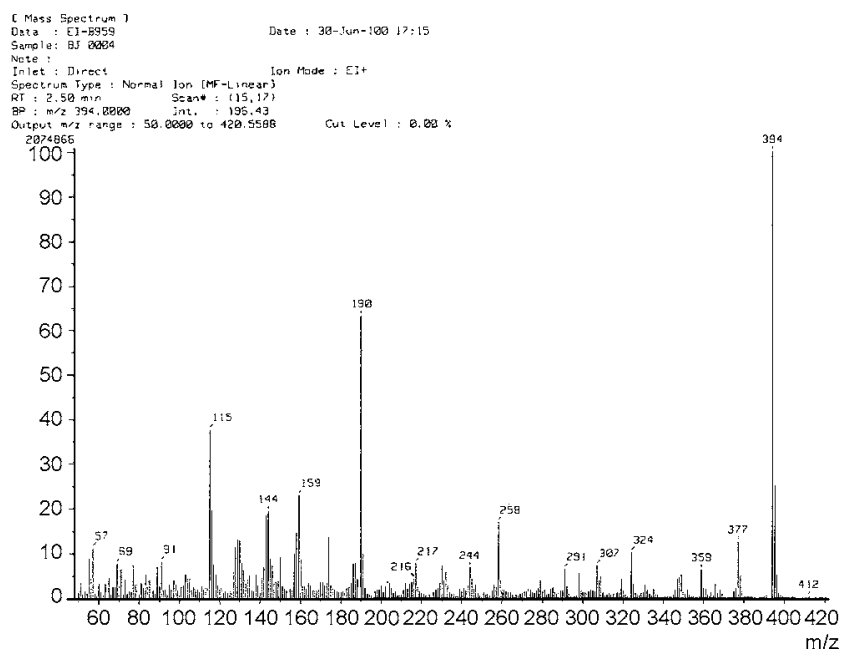

Figure 2. ${ }^{1} \mathrm{H}$ NMR spectrum of 1,7-bis(4-methyl-3-nitrophenyl)1,6-heptadiene-3,5-dione (BJC004) (a), Mass spectrum of 1,7bis (4-methyl-3-nitrophenyl)-1,6-heptadiene-3,5-dione (BJC004) (b).

were $>95 \%$ homogeneous as determined by SDS-PAGE. The concentrations of proteins were determined by Bradford assay. The concentrations of purified Jun and Fos were 129 $\mu \mathrm{L} / \mathrm{mL}$ and $36.74 \mu \mathrm{L} / \mathrm{mL}$ respectively. Purified Jun and Fos heterodimerize to form Jun-Fos-AP-l complex with $20 \mathrm{mM}$ DTT. We could identify Jun-Fos-AP-l complex in low concentration on EMSA but Jun-Jun-AP-1 and Fos-Fos-APl complex could not be identified in low concentration. On the other hand. broken Fos was also purified and formed Jun-Fos-AP-l complex. All of them could form complex with high efficiency when DTT was added.

Inhibitory effect of curcumin derivatives on EMSA (gel retardation assay). We investigated how some curcumin derivatives inhibit the formation of Fos-Jun-DNA (a)

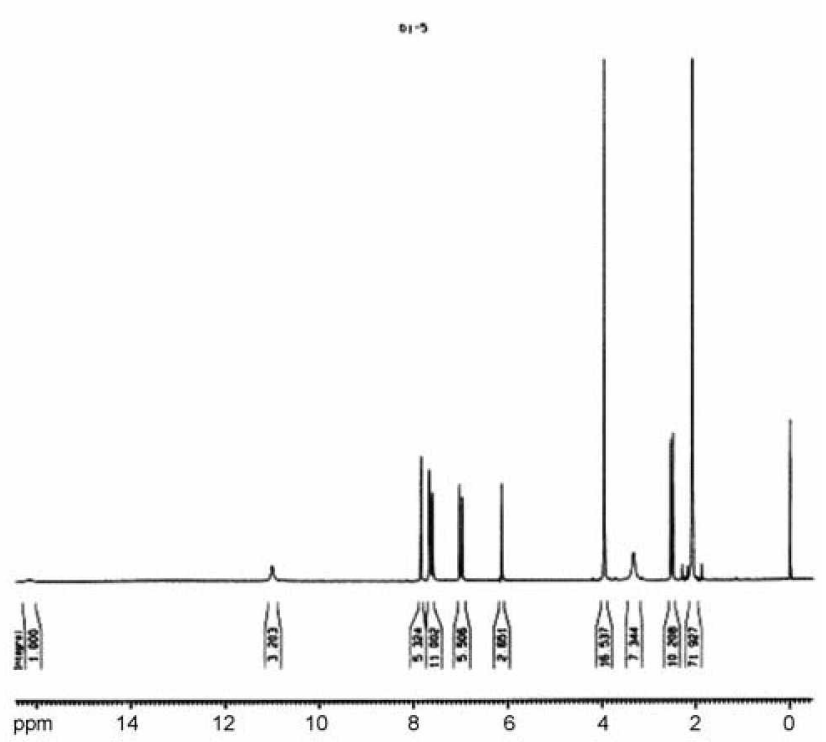

(b)

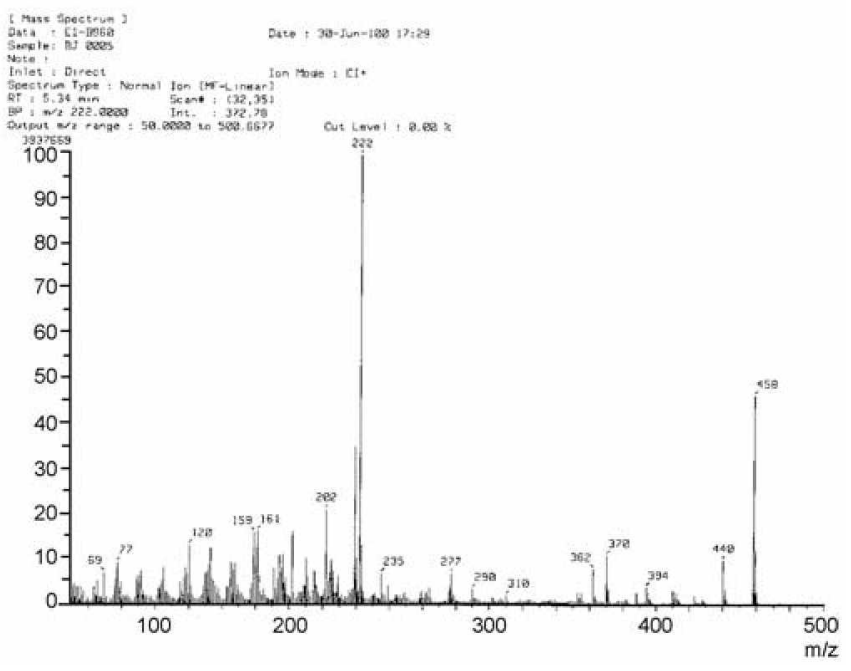

Figure 3. 'H NMR spectrum of 1,7-bis(4-hydrosy-5-methosy-3nitrophenyl)-1,6-heptadiene-3,5-dione (BJC005) (a), MS spectrum of 1,7-bis(4-hydroxy-5-methoxy-3-nitrophenyl)-1,6-heptadiene3,5-dione (B.JCOO5) (b).

complex. Especially 1.7-bis(4-methyl)-1.6-heptadiene-3.5dione (BJC003) and 1.7-bis(4-hydroxy-5-methoxy-3-nitrophenyl)-1.6-heptadiene-3.5-dione (BJC005) were confimed as remarkably potent inhibitors of Jun-Fos-AP-l complex. The activity was quantified with a liquid scintillation counter by checking the corresponding band. The activities of those compounds are shown in Figures 4 and 5 . IC $\mathrm{IC}_{5.1 .} 50 \%$ inhibition concentration of 1.7-bis(4-methyl)-1.6-heptadiene3.5-dione(BJC003) and 1.7-bis(4-hydroxy-5-methoxy-3nitrophenyl)-1.6-heptadiene-3.5-dione (BJC005), were 8.98 $\mu \mathrm{M}$ and $5.40 \mu \mathrm{M}$. respectively: Remarkably. BJC005 exhibits a much greater inhibitory effect than momordin. reported hitherto as the best Fos-Jun-DNA complex

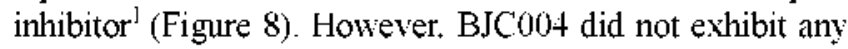
inhibitory activity against Fos-Jun-DNA complex formation 


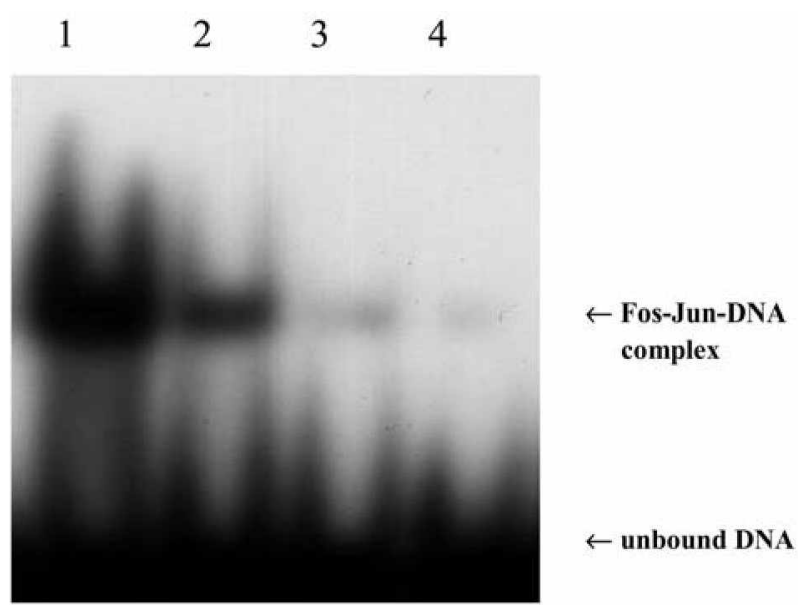

Figure 4. Inhibitory effect of 1,7-bis(4-methyl)-1,6-heptadiene3,5-dione (B.TCO03) on EMSA. The positions of unbound DNA and purified tos-Tun-DNA complex are indicated. "'P-radiolabeled AP-I DNA was used. All inlibitors were dissolved in DMSO and used in $0.44 \mathrm{mM}$. The concentrations of Fos-Tun heterodimer and DNA are $0.191 \mu \mathrm{M}$ and $0.194 \mathrm{mM}$, respectively. Lante $\mathrm{l}$ : positive control (DMSO instead of inhibitor), Lane 2: 1,7-bis(4-methyl)1,6-heptadiene-3,5-dione (13.3 $\mu \mathrm{M})$, Lane 3: 1,7-bis(4-methyl)1,6-heptadiene-3,5-dione ( $25 \mu \mathrm{M})$, Lane 4: 1,7-bis(4-methyl)-1,6heptadiene-3,5-dione (50 $\mu \mathrm{M})$.

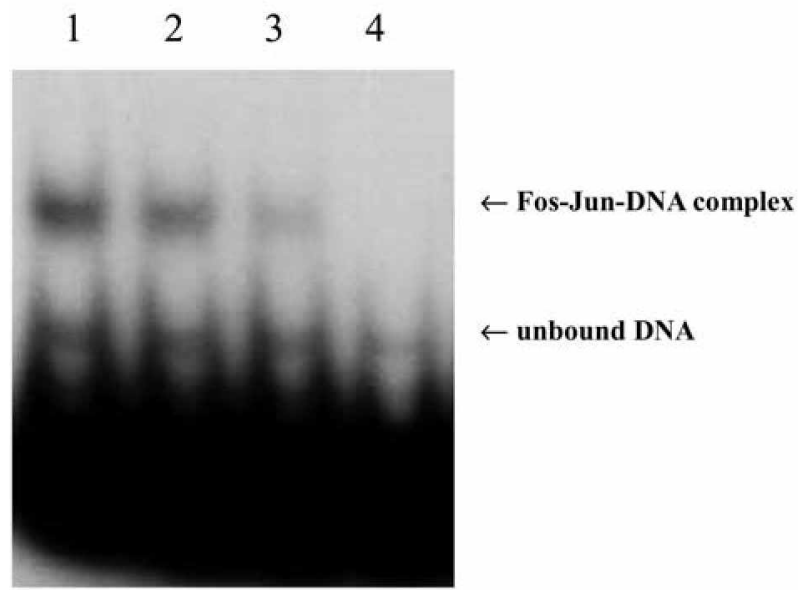

Figure 5. Inhibitory effect of 1,7-bis(4-hydroxy-5-methosy-3nitrophenyl)-1,6-heptadiene-3,5-dione (B.TC005) on EMSA. Lane I: positive control, Lane 2: 1,7-bis(4-hydroxy-5-methoxy-3nitrophenvl)-1,6-heptadiene-3,5-dione $(4 \mu \mathrm{M})$, Lane 3: 1,7-bis(4hydrosy-5-methosy-3-nitrophenyl)-1,6-heptadiene-3,5-dione (40) $\mu \mathrm{M})$, Lane 4: 1,7-bis(4-hydrosy-5-methoxy-3-nitropheny 1)-1,6heptadiene-3,5-dione ( $400 \mu \mathrm{M})$.

(Fig. 6). In the same system. the $\mathrm{IC}_{5 i}$ values of curcumin and momordin are $480 \mu \mathrm{M}$ and $186 \mu \mathrm{M}$. respectively. On the other hand. 1.7-bis(4-methy 1-3-nitrophenyl)-1,6-heptadiene3.5-dione(BJCO04) did not show inhibitory activity for Junfos-AP-1 complex (Fig. 6). A slight modification of the benzaldehyde moiety in the curcumin analogs structure affected the inhibition of Fos-Jun and DNA complex formation. Our data showed that the polarity of the substituted group acts as a parameter of inhibition. In other

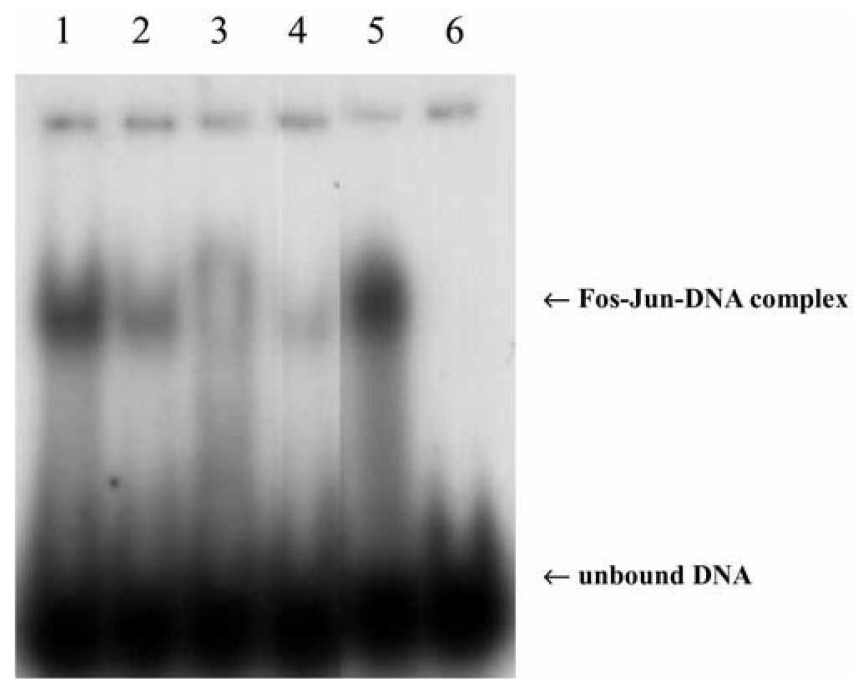

Figure 6. Comparison of inhibitory effect. Lane 1: Positive control, Lanes 2: momordin, Lanes 3: culcumin, Lanes 4: B.IC $003(0.2$ mM), Lane 5: B.JCO(04 (0.2 mM), Lane 6: B.TC005 (0.2 mM).

words. $p$-position- and polar-group-substituted curcumin analogs have a tendency to inhibit the Fos-Jun-DNA complex fonmation more potently. Since we lack of a complete understanding of the inhibitory action of curcumin analogs. we could not clearly explain these results. However. we suggest that many substitutions of polar groups to benzene rings offer a richly negative charge to the molecule itself. so they become potent competitors to DNA for interaction with the protein. Insertion of a nitro group into the benzene ring might contribute to improve the inhibitory activity.

These curcumin analogs showing high inhibitory activities can be utilized to define the inhibition of the cancer-related transcription factor. Fos-Jun heterodimer, and to design a potent anticancer agent. Therefore. this structural infonmation provides crucial clues for further studies. Judging from the chemical genonics. these curcumin analogs could also serve as the best intermediaries for achieving a complete understanding of the intracellular function of Fos-Jun heterodimer.

\section{Conclusions}

We succeeded in establishing the basis of a superior assay system with pure Jun and Fos and the synthesis of curcumin derivatives with an inhibitory effect for Jun-Fos-AP-1 complex. Their inhibitory activities were also shown to be stronger than curcumin and momordin. Jun and Fos including a His-tag could be purified by an $\mathrm{Ni}^{2+}$ colunn. Moreover, they can be dimerized in the optimized buffer solution. Curcumin derivatives were well șythesized by a high-temperature method as compared with the roomtemperature method published by H. J. J. Pabon.? Two curcumin derivatives showed higher activity than curcumin on EMSA

In sunmmary. our results clearly demonstrated that synthesized curcumin analogs. such as BJC003 and BJCOO4 show 
more potent inhibitory activities against Fos-Jun-DNA complex formation than curcumin and momordin. Further study is required to determine the precise molecular mechanism of inhibition by curcuminoids.

Acknowledgements. This work was supported by the Korea Research Foundation Grant (KRF-2001-015-DP0344). Financial support in part from the Brain Korea 21 Progran to Hahn and Park is gratefully acknowledged.

\section{References}

1. Lee. D. K. et al Anticancer Research 1998. 18. 119-124.

2. Pabon. H. J. J. Rect. Trav Chim. Pays-Bas 1964. 83. 379-386.

3. Toshiya. M.: Akiko, J. J. Agric. Food Chem. 1994, 42. 18501856.

4. Cony. A.; Daniel, L.: Tom. C. Molecular and Celhular Biology
1991. $11,3624-3632$

5. Abate. C.: Luk. D:: Gentz. R: Rauscher. F. T.: Curran. T. Pro. Natl. Acad Sci. USA 1990.87. 1032-1036.

6. Angel. P. E.: Herrlich. P. A. The Fos and Jnt Fanilies of Transcription Factors: CRC press: U.S.A., 1994: pp 169-286.

7. Smith. P. K.; Kroln. R. I.: Hermanson, G. T:; Mallia. A. K: Gartner. F. H.: Provenzano, M. D.: Fujimoto, E. K.: Goeke. N. M: Olson. B. T.: Klenk. D. C. Anal Biochem. 1985. 150. 76-85.

8. Kerppola. T. K.: Curran. T. Cell 1991. 66.317-326.

9. Salvatore. S.: Ant1a. M.: Bruno. M.: Lucianı. D. C.: Gabriele. D.: Roceo. D. P; Francesco, B.: Massimo, L.: Arduino. $O$. Biochimica et Biophysica Acta 1999, 1430. 103-110.

10. Silvia. V: Alessandra, C.; Jan, N.; Kirk, S.: Mauro. G.: Alberto. V. Protein Expression and Purification 1999. 15. 8-15.

11. Qi. H.: Liping. W.: Michael. F.: Carlos. E. C. The Jom of Biological Chentistry: 1999. 27t. 15305-14314.

12. Slawomir. D.: Jozef, K. Protein Expression and Purification 1999. 16. 96-102.

13. Lullien-Pellerin. V. et al. Eu: J. Biochem. 1999, 260,861-868. 